\title{
SIKAP PETANI TEMBAKAU VIRGINIA TERHADAP PROGRAM KEMITRAAN PT. EXPORT LEAF INDONESIA DI PULAU LOMBOK
}

\author{
Bagus Juniarta Purnama ${ }^{1}$, Hirwan Hamidi ${ }^{2}$, Taslim Sjah ${ }^{3}$ \\ ${ }^{1}$ PT Eli Nusa Tenggara Barat \\ ${ }^{2,3}$ Sosial Ekonomi, Universitas Mataram
}

INFO ARTIKEL
RiwayatArtikel:
Diterima: 07-07-2017
Disetujui: 20-08-2017

\section{Kata Kunci:}

Sikap Petani

Tembakau Virginia

Kemitraan

Pulau Lombok

\begin{abstract}
ABSTRAK
Abstrak: Budidaya komoditas tembakau memerlukan peran serta pengusaha besar (pemilik modal) untuk membantu mengembangkan usahatani petani kecil dalam bentuk kemitraan. Penelitian ini bertujuan untuk : 1) mengkaji karakteristik faktor-faktor pembentuk sikap petani tembakau Virginia dalam program kemitraan dengan PT. Export Leaf Indonesia di Pulau Lombok; 2) mengkaji sikap petani tembakau Virginia terhadap program kemitraan PT. Export Leaf Indonesia; 3) mengkaji hubungan antara faktor-faktor pembentuk sikap petani dengan sikap petani tembakau Virginia terhadap program kemitraan PT. Export Leaf Indonesia. Penentuan sampel lokasi menggunakan metode multiple stage sampling yaitu Kabupaten Lombok Timur dan Kabupaten Lombok Tengah. Penentuan responden dilakukan dengan metode simple random sampling. Jumlah petani sampel sebanyak 15 orang tiap desa terpilih sehingga seluruhnya 75 orang, yang merupakan mitra agribisnis tembakau Virginia PT. Export Leaf Indonesia (PT. ELI). Data yang terkumpul dianalisis secara deskriptif dengan menggunakan sistem kategori, teknik scoring skala Likert dan statistik nonparametrik uji korelasi Spearman (rs). Hasil penelitian menunjukkan bahwa sikap petani tembakau terhadap tujuan dan manfaat kemitraan dalam program kemitraan PT. ELI tergolong dalam kategori baik. Terdapat hubungan yang signifikan dan positif antara faktor pembentuk sikap dengan sikap petani tembakau terhadap program kemitraan PT. ELI.
\end{abstract}

\section{A. LATAR BELAKANG}

Visi pembangunan pertanian yang bertujuan membangun sistem agribisnis yang kuat berkesinambungan antar sektor dan antar wilayah sangat memerlukan teknologi pertanian untuk pengembangan komoditas yang berorentasi pasar serta sistem pelayanan bagi petani baik dalam hal teknik budidaya serta penyediaan modal usaha (kredit) dan penyuluhan pertanian sehingga diharapkan dapat meningkatkan komoditas-komoditas pertanian di era pasar bebas.

Komoditas tembakau merupakan salah satu komoditas pertanian yang berorientasi pasar dan mempunyai peran penting di masyarakat yaitu dapat menumbuhkan banyak kesempatan kerja baik dengan petani sebagai penghasil bahan baku proses produksi ataupun perusahaan sebagai tempat pengolahan hasil produksi. Selain itu tembakau juga memberikan sumbangan finansial yang berarti bagi bangsa Indonesia karena peranan tembakau yang semula utamanya memberikan sumbangan pada devisa negara bergeser menjadi sumbangan cukai terbesar setelah minyak bumi pada penerimaan negara [1].

Mengingat budidaya komoditas tembakau memerlukan permodalan yang besar serta kondisi petani Indonesia yang sangat lemah baik dalam hal manajemen dan profesionalisme serta terbatasnya akses terhadap permodalan, teknologi dan jaringan pemasaran maka diperlukan peran serta pengusaha besar (pemilik modal) untuk membantu mengembangkan usahatani petani kecil dalam bentuk kemitraan. Kemitraan usaha merupakan suatu bentuk kerjasama yang tepat untuk mengatasi permasalahan petani tersebut. Kemitraan dikembangkan atas dasar aspek ekonomis dan dengan pembinaan untuk menghasilkan manfaat jangka panjang. Dampak dari program kemitraan diharapkan tidak hanya menguntungkan para pelaku ekonomi atau perusahaan saja melainkan juga harus membawa dampak positif bagi seluruh kehidupan petani. Hubungan kemitraan diharapkan dapat menyelesaikan segala permasalahan seperti dalam hal permodalan, teknologi, saprodi, penetapan harga serta pemasaran hasil dengan mendapat bantuan dari pihak luar [2].

Salah satu wilayah pengembangan tembakau virginia di Indonesia adalah Pulau Lombok, yang menyumbang $68,95 \%$ dari total produksi nasional. Dibandingkan dengan wilayah-wilayah lainnya di Indonesia, Pulau Lombok memiliki keunggulan komparatif dalam pengembangannya.

Keunggulan-keunggulan inilah menyebabkan perusahaan pembeli tembakau berskala nasional bahkan multinasional masuk ke dalam bisnis tembakau virginia melalui pola kemitraan. 
Kemitraan PT. Export Leaf Indonesia yang sebelumnya adalah PT BAT Indonesia, telah dilaksanakan sejak tahun 1971, dan telah menimbulkan respon dari petani melalui rangsangan sosial dan reaksi yang bersifat emosional, sehingga menimbulkan sikap saling berinteraksi satu sama lain.

PT. Export Leaf Indonesia (PT. ELI) melakukan kemitraan dengan petani tembakau Virginia di Pulau Lombok melalui pengembangan pola inti plasma antara perusahaan mitra yaitu PT. ELI sebagai perusahaan inti dengan petani sebagai kelompok mitra. Kemitraan yang terjalin diartikan sebagai kerjasama yang sinergis antara dua belah pihak untuk melaksanakan suatu kegiatan sehingga tercipta hubungan timbal balik, saling menerima dan saling memberi satu sama lain. Keberhasilan program kemitraan yang terjalin antara PT. ELI dengan petani sangat ditentukan oleh sikap masing-masing peserta kemitraan itu sendiri karena semakin baik sikap peserta kemitraan maka semakin baik pula kemitraan yang terjalin.

Penelitian ini bertujuan untuk : 1) mengkaji karakteristik faktor-faktor pembentuk sikap petani tembakau Virginia dalam program kemitraan dengan PT. Export Leaf Indonesia di Pulau Lombok; dan 2) mengkaji sikap petani tembakau Virginia terhadap program kemitraan PT Export Leaf Indonesia; 3) mengkaji hubungan antara faktor-faktor pembentuk sikap petani dengan sikap petani tembakau Virginia terhadap program kemitraan PT Export Leaf Indonesia di Pulau Lombok.

\section{B. METODE PENELITIAN}

Penelitian ini menggunakan metode deskriptif, dengan unit analisis dipilah kedalam dua kelompok, yaitu individu-individu petani (agent) dan perusahaan yang bertindak sebagai principle dalam hubungan kerja kemitraan agribisnis tembakau virginia.

Penentuan sampel lokasi menggunakan metode multiple stage sampling, yaitu suatu sampel yang ditarik secara bertingkat mulai dari tingkat kabupaten hingga tingkat desa. Penentuan sampel lokasi kabupaten diambil berdasarkan pertimbangan jumlah petani tembakau terbanyak yaitu Kabupaten Lombok Timur dan Kabupaten Lombok Tengah.

Penentuan sampel lokasi kecamatan berdasarkan pertimbangan banyaknya populasi petani di masingmasing kecamatan, yaitu Kecamatan Kopang dan Kecamatan Janapria di Kabupaten Lombok Tengah, serta Kecamatan Terara, Kecamatan Sakra, dan Kecamatan Sakra Barat di Kabupaten Lombok Timur.

Penentuan sampel lokasi desa berdasarkan pertimbangan banyaknya populasi petani di masingmasing desa, maka untuk Kabupaten Lombok Tengah diambil satu desa di Kecamatan Kopang (Desa Montong Gamang Selatan) dan satu desa di Kecamatan Janapria (Desa Saba). Di Kabupaten Lombok Timur diambil satu desa di Kecamatan Terara (Desa Jenggik), satu desa di
Kecamatan Sakra Barat (Desa Buntiang), dan satu desa di Kecamatan Sakra (Desa Sakra).

Penentuan responden dilakukan dengan metode simple random sampling. Jumlah petani yang dijadikan sampel sebanyak 15 orang tiap desa terpilih sehingga seluruhnya 75 orang, yang keseluruhannya melakukan kemitraan dalam agribisnis tembakau Virginia dengan PT. Export Leaf Indonesia (PT. ELI).

Data yang terkumpul dianalisis dengan beberapa cara yang disesuaikan dengan tujuan penelitian.

Untuk tujuan pertama, yaitu mengkaji sikap petani tembakau Virginia terhadap program kemitraan PT. ELI, dianalisis secara deskriptif dengan menggunakan sistem kategori, yaitu :

Kelas Kategori $=($ Nilai Tertinggi - Nilai Terendah $)$ /Jumlah Kelas

Keterangan : kategori adalah komponen program kemitraan yang dinilai

Untuk tujuan kedua, mengkaji karakteristik faktorfaktor pembentuk sikap petani tembakau Virginia dalam program kemitraan dengan PT. ELI, dilakukan dengan teknik scoring skala Likert dan dianalisis secara deskriptif (tabulasi sederhana).

Untuk tujuan ketiga, mengkaji hubungan antara faktor-faktor pembentuk sikap petani dengan sikap petani tembakau Virginia terhadap program kemitraan PT. ELI, dianalisis dengan menggunakan statistik nonparametrik uji korelasi Spearman ( $r s$ ) dengan formula [3] sebagai berikut :

$$
\begin{gathered}
n \\
6 \sum d_{i^{2}} \\
i=1 \\
\left.\hline--n^{2}-1\right)
\end{gathered}
$$

Keterangan :

rs $=$ koefisien korelasi Spearman

$\mathrm{di}=$ selisih ranking antara faktor-faktor pembentuk sikap dengan sikap petani dalam program kemitraan PT. ELI

$\mathrm{n}=$ jumlah pasangan ranking

Untuk menguji hipotesis signifikansi koefisien korelasi Spearman digunakan uji-z karena sampel yang diambil lebih dari $30 \quad(n>30)$ dengan tingkat kepercayaan 95\% dengan rumus z-hitung $=\mathrm{rs} \sqrt{ } \mathrm{n}-1$ [3].

\section{HASIL DAN PEMBAHASAN Faktor-faktor Pembentuk Sikap}

Terdapat empat faktor yang membentuk sikap petani, yaitu pengalaman pribadi, pengaruh orang lain yang dianggap penting, pendidikan formal, dan pendidikan non formal.

\section{Pengalaman Pribadi}

Pengalaman pribadi dilihat dari pengalaman responden membudidayakan tanaman tembakau, pengalaman responden menjadi anggota program kemitraan dengan PT. ELI, pengalaman dalam program 
kemitran dan pengalaman dalam memanfaatkan program kemitraan.

Tabel 1.

Distribusi Aspek-aspek Pengalaman Pribadi Responden Dalam Program Kemitraan PT ELI Tahun 2013

\begin{tabular}{|c|c|c|c|c|}
\hline No & $\begin{array}{c}\text { Aspek-aspek } \\
\text { Pengalaman Pribadi } \\
\text { dan Kategori }\end{array}$ & Skor & $\begin{array}{c}\text { Jumlah } \\
\text { Petani } \\
\text { Corang) }\end{array}$ & $\begin{array}{c}\text { Persen } \\
\text { tase } \\
(\%)\end{array}$ \\
\hline \multirow[t]{4}{*}{1} & Pengalaman & & & \\
\hline & $\begin{array}{l}\text { Berusahatani Tembakau } \\
\text { a. Rendah }(<6 \text { tahun })\end{array}$ & 1 & 21 & 28,0 \\
\hline & b. Sedang $(6-10$ & 2 & 15 & 20,0 \\
\hline & c. Tinggi (> 10 tahun) & 3 & 39 & 52,0 \\
\hline \multirow[t]{4}{*}{2} & Pangalaman menjadi & & & \\
\hline & Mitra PT ELI & 1 & 6 & 80 \\
\hline & b. Sedang $(2-5$ tahun $)$ & 2 & 27 & 36,0 \\
\hline & c. Tinggi ( $>5$ tahun) & 3 & 42 & 56,0 \\
\hline \multirow[t]{4}{*}{3} & Pengalaman & & & \\
\hline & $\begin{array}{l}\text { Permasalahan } \\
\text { a. Rendah (tidak ada } \\
\text { masalah) }\end{array}$ & 1 & 68 & 90,7 \\
\hline & $\begin{array}{l}\text { b. Sedang (jarang ada } \\
\text { masalah) }\end{array}$ & 2 & 7 & 9,3 \\
\hline & $\begin{array}{l}\text { c. Tinggi (selalu ada } \\
\text { masalah) }\end{array}$ & 3 & o & o \\
\hline \multirow[t]{3}{*}{4} & $\begin{array}{l}\text { Manfaat yang Diterima } \\
\text { dari PT ELI } \\
\text { a. Rendah (tidak ada } \\
\text { manfaat) }\end{array}$ & 1 & $\mathrm{O}$ & $\mathrm{O}$ \\
\hline & $\begin{array}{l}\text { b. Sedang (jarang ada } \\
\text { manfaat) }\end{array}$ & 2 & 5 & 6,7 \\
\hline & $\begin{array}{l}\text { c. Tinggi (selalu ada } \\
\text { manfaat) }\end{array}$ & 3 & 70 & 93,3 \\
\hline \multirow[t]{2}{*}{5} & Distribusi Pengalaman & $4-6$ & 1 & 1,3 \\
\hline & $\begin{array}{l}\text { Pribadi secara } \\
\text { kseluruhan dalam PT ELI }\end{array}$ & $\begin{array}{c}7-9 \\
10-12\end{array}$ & 40 & 53,4 \\
\hline
\end{tabular}

Sumber : Data primer diolah, Tahun 2013

Berdasarkan Tabel 1 diketahui persentase tertinggi lamanya responden membudidayakan tanaman tembakau sebesar $52 \%$ dengan waktu lebih dari 10 tahun dan persentase terendah sebesar 20\% membudidayakan tanaman tembakau antara 6-10 tahun. Rata-rata lamanya responden membudidayakan tanaman tembakau tergolong dalam kategori tinggi. Hal ini dikarenakan responden memanfaatkan lahan usahataninya dengan membudidayakan tanaman tembakau secara turun temurun dan menganggap tanaman tembakau dapat meningkatkan perekonomian.

Persentase tertinggi distribusi lamanya responden menjadi anggota program kemitraan yaitu lebih dari 5 tahun sebesar $56 \%$ dan persentase terendah sebesar $8 \%$ kurang dari 2 tahun. Rata-rata responden menjadi anggota kemitraan PT. ELI termasuk kategori tinggi yaitu lebih dari 5 tahun. Semakin lama responden menjadi anggota kemitraan maka semakin mengetahui program yang terdapat dalam kemitraan PT. ELI serta berpartisipasi aktif dalam program yang dijalankan.

Persentase tertinggi pengalaman pribadi responden terhadap permasalahan yang pernah dialami yaitu 90,7\% tidak pernah bermasalah dalam program kemitraan karena mereka sangat setuju terhadap program dan kebijakan yang ditetapkan oleh PT . ELI.

Persentase tertinggi pengalaman petani dilihat dari manfaat yang diterima responden dalam program kemitraan PT. ELI yaitu sebesar 93,3\% selalu mendapatkan manfaat dengan mengikuti program kemitraan. Responden mempunyai pengalaman pribadi yang baik yaitu dengan mengikuti kemitraan, mendapatkan manfaat dalam usaha membudidayakan tanaman tembakau serta dapat meningkatkan kesejahteraaan dan pendapatan responden.

Persentase tertinggi distribusi pengalaman pribadi petani secara keseluruhan dalam program kemitraan PT. ELI sebesar 53,4\% dan persentase terendah sebesar $1,3 \%$, sehingga rata-rata pengalaman pribadi petani dalam program kemitraan secara keseluruhan berada pada kategori sedang yang artinya responden selama ini mempunyai pengalaman pribadi yang cukup baik dalam proses budidaya tanaman tembakau dan cukup mempunyai pengalaman dalam menjadi anggota kemitraan PT. ELI.

\section{Pengaruh Orang Lain yang Dianggap Penting}

Pengaruh orang lain yang dianggap penting adalah orang-orang yang oleh petani dianggap penting sebagai panutan atau yang berperan memberikan saran, pendapat, ajakan atau bahkan perintah untuk mengikuti program kemitraan PT. ELI, diantaranya Dinas Perkebunan, Kepala Desa, Penyuluh Pertanian Lapang dari PT. ELI, dan Ketua kelompok tani. Distribusi pengaruh orang lain yang dianggap penting dalam program kemitraan PT. ELI dapat dilihat pada Tabel 2.

\section{Tabel 2.}

Distribusi Pengaruh Orang Lain yang Dianggap Penting dalam Program Kemitraan PT ELI Tahun 2013

\begin{tabular}{|c|c|c|c|c|}
\hline No & $\begin{array}{l}\text { Tokoh Panutan } \\
\text { dan Kategori }\end{array}$ & Skor & $\begin{array}{c}\text { Jumlah } \\
\text { Petani } \\
\text { (Orang) }\end{array}$ & $\begin{array}{c}\text { Persen } \\
\text { tase } \\
(\%)\end{array}$ \\
\hline 1 & $\begin{array}{l}\text { Dinas Perkebunan } \\
\text { a. Rendah } \\
\text { b. Sedang } \\
\text { c. Tinggi }\end{array}$ & $\begin{array}{l}1 \\
2 \\
3\end{array}$ & $\begin{array}{c}55 \\
20 \\
0\end{array}$ & $\begin{array}{c}73,3 \\
26,7 \\
0\end{array}$ \\
\hline 2 & $\begin{array}{l}\text { Kepala Desa } \\
\text { a. Rendah } \\
\text { b. Sedang } \\
\text { c. Tinggi }\end{array}$ & $\begin{array}{l}1 \\
2 \\
3\end{array}$ & $\begin{array}{l}19 \\
12 \\
44\end{array}$ & $\begin{array}{l}25,3 \\
16,0 \\
58,7\end{array}$ \\
\hline 3 & $\begin{array}{l}\text { Petugas Lapangan } \\
\text { dari PT ELI } \\
\text { a. Rendah } \\
\text { b. Sedang } \\
\text { c. Tinggi }\end{array}$ & $\begin{array}{l}1 \\
2 \\
3 \\
\end{array}$ & $\begin{array}{c}0 \\
0 \\
75 \\
\end{array}$ & $\begin{array}{c}0 \\
0 \\
100 \\
\end{array}$ \\
\hline 4 & $\begin{array}{l}\text { Ketua Kelompok Tani } \\
\text { a. Rendah } \\
\text { b. Sedang } \\
\text { c. Tinggi }\end{array}$ & $\begin{array}{l}1 \\
2 \\
3\end{array}$ & $\begin{array}{c}0 \\
0 \\
75\end{array}$ & $\begin{array}{c}0 \\
0 \\
100\end{array}$ \\
\hline 5 & $\begin{array}{l}\text { Distribusi Pengaruh } \\
\text { orang lain yang } \\
\text { dianggap penting } \\
\text { secara kseluruhan } \\
\text { a. Rendah } \\
\text { b. Sedang } \\
\text { c. Tinggi }\end{array}$ & $\begin{array}{c}4-6 \\
7-9 \\
10-12\end{array}$ & $\begin{array}{c}0 \\
23 \\
52\end{array}$ & $\begin{array}{c}0 \\
30,7 \\
69,3\end{array}$ \\
\hline
\end{tabular}

Sumber : Data primer diolah, Tahun 2013

Berdasarkan Tabel 2 diketahui persentase tertinggi intensitas pengaruh yang diberikan Dinas Perkebunan 
sebesar $73,3 \%$ dalam kategori rendah artinya Dinas Perkebunan tidak berpengaruh terhadap sikap petani dalam program kemitraan PT. ELI. Hal ini disebabkan saran, pendapat atau perintah dari Dinas Perkebunan kurang mendatangkan keuntungan bagi responden dan tidak semua anjuran atau saran yang diberikan tersebut seluruhnya dipenuhi oleh pemerintah.

Persentase tertinggi intensitas pengaruh Kepala Desa dalam program kemitraan PT. ELI sebesar 58,7\% dan persentase terendah sebesar $16 \%$. Rata-rata intensitas pengaruh Kepala Desa dalam program kemitraan berada dalam kategori tinggi. Kepala Desa berpengaruh terhadap perubahan sikap petani dalam program kemitraan. Saran, pendapat atau ajakan dari Kepala Desa dipatuhi oleh petani karena Kepala Desa termasuk tokoh masyarakat yang disegani dan dihormati oleh petani.

Penyuluh pertanian lapang dari PT. ELI berpengaruh terhadap sikap petani terutama dalam program kemitraan PT. ELI. Intensitas pengaruh penyuluh pertanian lapang PT. ELI dalam memberikan saran, ajakan dan masukan yang berkaitan terhadap keberlangsungan program kemitraan berada dalam kategori tinggi yang artinya $100 \%$ responden menganggap penyuluh pertanian lapang PT. ELI berpengaruh dan mempunyai peran penting dalam menyampaikan informasi tentang program kemitraan.

Ketua kelompok tani adalah seseorang yang memperoleh pengakuan dari anggota kelompoknya yang dipilih secara mufakat untuk menggerakkan anggotanya mencapai tujuan bersama. Tabel 2 menunjukkan bahwa intensitas pengaruh ketua kelompok tani terhadap sikap petani dalam program kemitraan PT. ELI tergolong tinggi yang artinya peran ketua kelompok tani berpengaruh $100 \%$ terhadap sikap petani terhadap pengambilan keputusan dalam program kemitraan. Dukungan dilakukan melalui ajakan untuk meningkatkan produksi dan nilai tambah dari tanaman tembakau, saran untuk mengikuti program kemitraan, serta informasi seputar teknik budidaya tanaman tembakau. Banyaknya dukungan dari pihak-pihak yang dianggap penting oleh petani menjadikan respon dan sikap petani terhadap kegiatan program kemitraan umumnya baik.

\section{Pendidikan Formal}

Pendidikan formal dalam penelitian ini adalah tingkat pendidikan yang pernah ditempuh oleh petani di bangku sekolah. Distribusi tingkat pendidikan formal petani dalam program kemitraan PT ELI dapat dilihat pada Tabel 3 .

Tabel 3.

Distribusi Tingkat Pendidikan Formal yang Ditempuh Responden Dalam Program Kemitraan PT. ELI

\begin{tabular}{|c|l|c|c|c|}
\hline No & $\begin{array}{c}\text { Pendidikan } \\
\text { Formal } \\
\text { yang ditempuh }\end{array}$ & Skor & $\begin{array}{c}\text { Jumlah } \\
\text { Petani } \\
\text { (Orang) }\end{array}$ & $\begin{array}{c}\text { Persen } \\
\text { tase } \\
\text { (\%) }\end{array}$ \\
\hline 1 & Tidak Sekolah & 1 & 3 & 4,0 \\
2 & Tamat SD & 2 & 26 & 34,7
\end{tabular}

\begin{tabular}{|l|l|c|c|c|}
3 & Tamat SMP - SMU & 3 & 39 & 52,0 \\
4 & Tamat Perguruaan & 4 & 7 & 9,3 \\
& Tinggi (S1) & & & \\
\hline & Jumlah & & 75 & 100 \\
\hline
\end{tabular}

Sumber : Data primer diolah, Tahun 2013

Tingkat pendidikan menentukan tingkat pemahaman, keterampilan berkomunikasi dan sikap petani terhadap suatu inovasi yang diterapkan. Tingkat pedidikan formal petani dalam program kemitraan berdasarkan Tabel 3 menunjukkan bahwa persentase sebesar 52\% tamat SMP sampai dengan tamat SMA dan persentase terendah sebesar 4,0\% tidak pernah sekolah, sehingga rata-rata distribusi pendidikan petani dalam program kemitraan PT. ELI berada dalam kategori sedang yaitu antara tamat SMP dan SMA.

Distribusi responden menurut pendidikan formalnya tergolong sedang karena responden tidak memiliki biaya untuk meneruskan pendidikan ke tingkat yang lebih tinggi. Tingkat pendidikan yang tergolong sedang mendukung responden menyerap inovasi yang diberikan dalam program kemitraan PT. ELI dengan lebih baik dan cepat daripada responden yang memiliki pendidikan dalam kategori rendah atau hanya tamat SD dan tidak pernah sekolah.

\section{Pendidikan Non Formal}

Pendidikan non formal dalam penelitian ini adalah pendidikan yang diperoleh petani di luar pendidikan formal. Pendidikan yang sasaran utamanya orang dewasa, memiliki program yang terencana, dapat dilakukan dimana saja, tidak terikat waktu serta disesuaikan dengan kebutuhan sasaran peserta didik. Pendidikan non formal yang terdapat dalam program kemitraan PT. ELI disajikan pada Tabel 4.

\section{Tabel 4.}

Distribusi Pendidikan non Formal Petani Dalam Program Kemitraan PT ELI Tahun 2013

\begin{tabular}{|c|c|c|c|c|}
\hline No & $\begin{array}{c}\text { Pendidikan non } \\
\text { Formal } \\
\text { dan Kategori }\end{array}$ & Skor & $\begin{array}{c}\text { Jumlah } \\
\text { Petani } \\
\text { (Orang) }\end{array}$ & $\begin{array}{c}\text { Persen } \\
\text { tase } \\
(\%)\end{array}$ \\
\hline \multirow[t]{3}{*}{1} & $\begin{array}{l}\text { Penyuluhan } \\
\text { a. Rendah (tidak } \\
\text { pernah) }\end{array}$ & 1 & 17 & 22,7 \\
\hline & & 2 & 10 & 13,3 \\
\hline & c. Tinggi ( $>2$ kali) & 3 & 48 & 64,0 \\
\hline \multirow[t]{3}{*}{2} & $\begin{array}{l}\text { Seminar } \\
\text { a. Rendah (tidak }\end{array}$ & 1 & 59 & 78,7 \\
\hline & $\begin{array}{l}\text { b. Sedang (1-2 } \\
\text { kali) }\end{array}$ & 2 & 16 & 21,3 \\
\hline & c. Tinggi ( $>2$ kali) & 3 & $\mathrm{O}$ & $\mathrm{O}$ \\
\hline \multirow[t]{3}{*}{3} & $\begin{array}{l}\text { Demonstrasi } \\
\text { a. Rendah (tidak } \\
\text { pernah) }\end{array}$ & 1 & 18 & 24,0 \\
\hline & b. Sedang $(1-2$ & 2 & 51 & 68,0 \\
\hline & c. Tinggi (> 2 kali) & 3 & 6 & 8,0 \\
\hline \multirow[t]{3}{*}{4} & $\begin{array}{l}\text { Kunjungan } \\
\text { a. Rendah (tidak } \\
\text { pernah) }\end{array}$ & 1 & 70 & 93,3 \\
\hline & $\begin{array}{l}\text { b. Sedang }(1-2 \\
\text { kali) }\end{array}$ & 2 & 5 & 6,7 \\
\hline & c. Tinggi (> 2 kali) & 3 & o & o \\
\hline 5 & $\begin{array}{l}\text { Distribusi Pendidikan } \\
\text { non Formal secara }\end{array}$ & & & \\
\hline
\end{tabular}




\begin{tabular}{|l|c|c|c|}
\hline keseluruhan & & & \\
a. Rendah & $4-6$ & 35 & 46,7 \\
b. Sedang & $7-9$ & 40 & 53,3 \\
c. Tinggi & $10-12$ & O & O \\
\hline
\end{tabular}

Sumber : Data primer diolah, Tahun 2013

Berdasarkan Tabel 4. diketahui persentase tertinggi pendidikan non formal responden dalam bentuk penyuluhan sebesar $64 \%$ responden sering mengikuti penyuluhan yang diadakan oleh petugas penyuluh lapang dari PT. ELI dan persentase terendah sebesar $13,3 \%$ responden jarang mengikuti penyuluhan. Ratarata distribusi pendidikan non formal responden dalam bentuk penyuluhan berada dalam kategori tinggi. Hal ini artinya responden selalu mengikuti penyuluhan yang diadakan oleh petugas penyuluh lapang dari PT. ELI lebih dari 2 kali. Mereka mendapatkan informasi, bimbingan, saran dan petunjuk berkaitan dengan budidaya tanaman tembakau.

Persentase tertinggi pendidikan non formal dalam bentuk seminar sebesar 78,7\% responden tidak pernah mengikuti seminar yang diadakan oleh PT. ELI dan persentase terendah sebesar $21,3 \%$ jarang mengikuti seminar yang diadakan, sehingga rata-rata distrribusi pendidikan non formal responden dalam bentuk seminar berada dalam kategori rendah artinya 59 responden tidak pernah mengikuti seminar yang diadakan oleh PT. ELI.

Persentase tertinggi distribusi pendidikan non formal responden dalam bentuk demonstrasi sebesar $68 \%$ jarang mengikuti demonstrasi yang diadakan oleh PT. ELI dan persentase terendah responden sebesar 8\% selalu mengikuti demonstrasi, sehingga rata-rata distribusi pendidikan formal responden dalam bentuk demonstrasi berada dalam kategori sedang. Hal ini artinya 51 responden pernah mengikuti demonstrasi 1 sampai 2 kali pertemuan.

Persentase tertinggi dari distribusi pendidikan non formal responden dalam bentuk kunjungan sebesar 93,3\% tidak pernah mengikuti kunjungan yang diadakan oleh PT. ELI, sedangkan persentase terendah sebesar 6,7\% pernah mengikuti kunjungan 1 sampai 2 kali. Rata-rata distribusi pendidikan non formal responden dalam bentuk kunjungan berada dalam kategori rendah yaitu 70 responden tidak pernah mengikuti kunjungan yang diadakan oleh PT. ELI.

Persentase pendidikan non formal responden secara keseluruhan yaitu sebesar $53,3 \%$ atau 40 responden berada dalam kategori sedang yang artinya minat dan kesadaran petani terhadap kegiatan pelatihan seperti demonstrasi, kunjungan serta seminar cukup memadai, sehingga responden tetap mengikuti kegiatan penyuluhan rutin yang dilaksanakan oleh penyuluh pertanian dari PT. ELI untuk dapat menambah pengetahuan dan keterampilan mengelola usahataninya.

\section{Sikap Petani Tembakau Terhadap Program Kemitraan PT. ELI}

Sikap petani tembakau terhadap program
Kemitraan PT. ELI adalah tanggapan atau respon evaluatif petani responden terhadap segala bentuk kegiatan dalam program Kemitraan PT. ELI berupa sikap setuju, kurang setuju atau tidak setuju. Komponen program kemitraan yang dinilai meliputi : tujuan kemitraan, pemberian pinjaman modal, sarana produksi (benih, pupuk, pestisida, dan teknologi / peralatan usaha tani), pemasaran hasil, penetapan harga, dan manfaat kemitraan. Sikap petani tembakau terhadap program Kemitraan PT. ELI di Pulau Lombok berdasarkan analisis dapat dilihat pada Tabel 5 .

\section{Tabel 5.}

Distribusi Sikap Petani Tembakau Virginia Terhadap Program Kemitraan PT. ELI di Pulau Lombok Tahun 2013

\begin{tabular}{|c|c|c|c|c|}
\hline No & $\begin{array}{c}\text { Sikap Petani } \\
\text { Terhadap Program } \\
\text { Kemitraan dan } \\
\text { Kategori }\end{array}$ & Skor & $\begin{array}{c}\text { Jumlah } \\
\text { Petani } \\
\text { (Orang) }\end{array}$ & $\begin{array}{c}\text { Persen } \\
\text { tase } \\
(\%)\end{array}$ \\
\hline 1 & $\begin{array}{l}\text { Tujuan Kemitraan } \\
\text { a. Buruk } \\
\text { b. Cukup Baik } \\
\text { c. Baik }\end{array}$ & $\begin{array}{c}4-6 \\
7-9 \\
10-12\end{array}$ & $\begin{array}{c}0 \\
0 \\
75\end{array}$ & $\begin{array}{c}0 \\
0 \\
100\end{array}$ \\
\hline 2 & $\begin{array}{l}\text { Pemberian Pinjaman } \\
\text { Modal/Kredit } \\
\text { a. Buruk } \\
\text { b. Cukup Baik } \\
\text { c. Baik }\end{array}$ & $\begin{array}{l}1-2 \\
3-4 \\
5-6\end{array}$ & $\begin{array}{c}0 \\
0 \\
75\end{array}$ & $\begin{array}{c}0 \\
0 \\
100\end{array}$ \\
\hline 3 & $\begin{array}{l}\text { Pemberian Pinjaman } \\
\text { Saprodi : } \\
\text { 1. Pemberian saprodi } \\
\text { benih } \\
\text { a. Buruk } \\
\text { b. Cukup Baik } \\
\text { c. Baik }\end{array}$ & $\begin{array}{l}1-3 \\
4-6 \\
7-9\end{array}$ & $\begin{array}{c}0 \\
6 \\
69 \\
\end{array}$ & $\begin{array}{c}0 \\
8,0 \\
92,0\end{array}$ \\
\hline & $\begin{array}{l}\text { 2. Pemberian saprodi } \\
\text { pupuk } \\
\text { a. Buruk } \\
\text { b. Cukup Baik } \\
\text { c. Baik }\end{array}$ & $\begin{array}{l}1-3 \\
4-6 \\
7-9\end{array}$ & $\begin{array}{c}0 \\
9 \\
66 \\
\end{array}$ & $\begin{array}{c}0 \\
12,0 \\
88,0\end{array}$ \\
\hline & $\begin{array}{l}\text { 3. Pemberian saprodi } \\
\text { pestisida } \\
\text { a. Buruk } \\
\text { b. Cukup Baik } \\
\text { c. Baik }\end{array}$ & $\begin{array}{c}1-3 \\
4-6 \\
7-9\end{array}$ & $\begin{array}{l}0 \\
8 \\
67\end{array}$ & $\begin{array}{c}0 \\
10,7 \\
89,3\end{array}$ \\
\hline & $\begin{array}{l}\text { 4. Pemberian } \\
\text { teknologi usahatani } \\
\text { a. Buruk } \\
\text { b. Cukup Baik } \\
\text { c. Baik }\end{array}$ & $\begin{array}{l}1-3 \\
4-6 \\
7-9\end{array}$ & $\begin{array}{c}0 \\
3 \\
72\end{array}$ & $\begin{array}{c}0 \\
4,0 \\
96,0\end{array}$ \\
\hline 4 & $\begin{array}{l}\text { Pemasaran Hasil } \\
\text { a. Buruk } \\
\text { b. Cukup Baik } \\
\text { c. } \\
\end{array}$ & $\begin{array}{l}1-2 \\
3-4 \\
5-6 \\
\end{array}$ & $\begin{array}{c}0 \\
2 \\
73 \\
\end{array}$ & $\begin{array}{c}0 \\
2,7 \\
97,3 \\
\end{array}$ \\
\hline 5 & $\begin{array}{l}\text { Penetapan Harga } \\
\text { a. Buruk } \\
\text { b. Cukup Baik } \\
\text { c. Baik }\end{array}$ & $\begin{array}{l}1-2 \\
3-4 \\
5-6\end{array}$ & $\begin{array}{c}0 \\
0 \\
75\end{array}$ & $\begin{array}{c}0 \\
0 \\
100\end{array}$ \\
\hline 6 & $\begin{array}{l}\text { Manfaat Kemitraan } \\
\text { a. Buruk } \\
\text { b. Cukup Baik } \\
\text { c. Baik }\end{array}$ & $\begin{array}{c}4-6 \\
7-9 \\
10-12\end{array}$ & $\begin{array}{c}\mathrm{O} \\
\mathrm{O} \\
75\end{array}$ & $\begin{array}{c}0 \\
0 \\
100\end{array}$ \\
\hline 7 & $\begin{array}{l}\text { Sikap petani terhadap } \\
\text { program kemitraan PT. } \\
\text { ELI (Y total) } \\
\text { a. Buruk } \\
\text { b. Cukup Baik } \\
\text { c. Baik }\end{array}$ & $\begin{array}{l}15-36 \\
37-58 \\
59-80\end{array}$ & $\begin{array}{c}0 \\
0 \\
75\end{array}$ & $\begin{array}{c}0 \\
0 \\
100\end{array}$ \\
\hline
\end{tabular}

Sumber : Data primer diolah, Tahun 2013 
Sikap Petani Tembakau Terhadap Tujuan Kemitraan PT. ELI

Sikap petani tembakau terhadap tujuan kemitraan adalah tanggapan atau respon evaluatif petani responden terhadap tujuan program kemitraan dengan PT. ELI dalam hal meningkatkan kualitas SDM petani terhadap pengelolaan usahatani, meningkatkan kualitas SDM petani terhadap proses distribusi, meningkatkan jumlah produksi tembakau dengan peningkatan kualitas yang lebih baik setiap kali musim tanam dan meningkatkan pendapatan petani tembakau.

Hasil analisis pada Tabel 5 menunjukkan bahwa sikap petani tembakau terhadap tujuan kemitraan tergolong dalam kategori baik sebanyak $100 \%$ atau 75 responden. Responden telah mengetahui kejelasan tujuan program kemitraan bagi petani dan anggota kelompok tani, serta peran dan fungsi tujuan program kemitraan bagi petani dalam mengelola usahataninya. Tujuan dari program kemitraan tersebut telah memberikan motivasi besar bagi petani untuk meningkatkan kemampuan mengembangkan usahataninya, baik dalam hal meningkatkan keterampilan dalam budidaya tanaman tembakau, peningkatan pendapatan petani, pendistribusian dan penyaluran hasil panen serta peningkatan jumlah produksi tembakau dalam program kemitraan PT. ELI.

\section{Sikap Petani Tembakau Terhadap Pemberian Pinjaman Modal}

Sikap petani tembakau terhadap pemberian pinjaman modal atau kredit adalah tanggapan atau respon evaluatif petani responden terhadap pemberian pinjaman modal dari PT. ELI yang digunakan untuk budidaya tanaman tembakau yang meliputi jumlah pinjaman yang diberikan dan ketepatan waktu pemberian pinjaman kepada petani. Rata-rata pinjaman modal yang diberikan dalam program kemitraan PT. ELI per petani sebesar $\mathrm{Rp} 6.134 .500 /$ ha yang digunakan untuk biaya sarana produksi sebesar Rp 4.454.454/ha, biaya tenaga kerja sebesar Rp 838.507/ha, dan biaya lain-lain Rp 841.539/ha.

Berdasarkan Tabel 5 dapat dilihat bahwa persentase tertinggi sikap petani terhadap pemberian pinjaman modal kemitraan PT. ELI sebesar $100 \%$ atau 75 responden setuju terhadap jumlah pemberian pinjaman modal serta ketepatan waktu dari PT ELI. Rata-rata sikap petani tembakau terhadap pemberian pinjaman modal tergolong dalam kategori baik. Jumlah pinjaman modal yang telah diterima oleh responden dari PT. ELI dirasa sudah cukup memadai untuk proses budidaya tanaman tembakau yang terdiri dari biaya tenaga kerja, biaya panen dan biaya pengolahan hasil. Pemberian pinjaman modal tersebut juga sudah tepat waktu yaitu pada awal musim tanam atau tidak mengalami keterlambatan dan sesuai dengan kebutuhan responden.

Sikap Petani Tembakau Terhadap Pengadaan Saprodi (Benih, pupuk, Pestisida, dan Teknologi atau Peralatan Usahatani)
Sikap petani tarhadap bantuan pemberian pinjaman benih adalah tanggapan atau respon evaluatif petani responden terhadap bantuan sarana produksi benih dari PT. ELI yang digunakan untuk budidaya tanaman tembakau berkaitan dengan jumlah bantuan yang diberikan, harga yang ditetapkan serta ketepatan waktu pemberian benih tersebut kepada petani. Ada 5 varietas bibit yang digunakan dalam program kemitraan ini yaitu NC 297 (Goldleaf Seed Amerika), C 176 (Goldleaf Seed Amerika), RGH o4 (Rijkard Seed Amerika), LK 101 (Larss Seed Afrika Selatan) dan CC 506 (Crosscreek Seed Amerika). Kebutuhan 1 hektar adalah 3 gram bibit tembakau dengan harga bibit berkisar Rp 15.000 - Rp 35.000 per gram.

Berdasarkan Tabel 5 dapat dilihat bahwa persentase tertinggi sikap petani tembakau terhadap pemberian pinjaman saprodi benih dalam program kemitraan PT. ELI sebesar 92\% atau 69 responden bersikap baik, sedangkan persentase terendah sebesar 8\% atau 6 responden bersikap cukup baik, sehingga rata-rata sikap petani tembakau terhadap pemberian pinjaman saprodi benih berada dalam kategori baik. Semua responden telah menerima bantuan pinjaman benih dengan jumlah yang cukup yaitu sebesar 4-5 gr/ha untuk proses budidaya tanaman tembakau sehingga mereka tidak membutuhkan tambahan jumlah pinjaman dari PT. ELI. Harga satu gram bibit tembakau yang ditetapkan telah sesuai yaitu sebesar Rp 15.000 Rp 35.000/gr tergantung varietas yang diinginkan oleh petani. Waktu pemberian bibit selama ini juga tidak pernah mengalami keterlambatan atau selalu tepat waktu sesuai dengan kebutuhan petani yaitu pada awal musim tanam.

Berdasarkan Tabel 5 dapat dilihat bahwa persentase tertinggi sikap petani terhadap pemberian pinjaman saprodi pupuk dalam program kemitraan PT. ELI sebesar 88\% atau 66 responden bersikap baik dan persentase terendah sebesar $12 \%$ atau 9 responden bersikap cukup baik. Rata-rata sikap petani tembakau terhadap pemberian pinjaman saprodi pupuk tergolong dalam kategori baik. Pupuk yang digunakan dalam 1 ha budidaya tanaman tembakau yaitu pupuk Fertila $450 \mathrm{~kg}$ dengan harga Rp 6.579/kg, pupuk $\mathrm{KNO}_{3}$ sebesar 300 kg dengan harga Rp 15.237/kg, dan pupuk SP36 sebesar $100 \mathrm{~kg}$ dengan harga Rp 2400/kg.

Jumlah pemberian pinjaman saprodi pupuk dalam program kemitraan PT. ELI selama ini cukup untuk proses budidaya tanaman tembakau, harga yang ditetapkan juga sesuai serta waktu pemberian pinjaman saprodi pupuk tersebut tidak mengalami keterlambatan atau selalu tepat waktu yaitu pada awal musim tanam.

Berdasarkan Tabel 5 dapat dilihat bahwa persentase tertinggi sikap petani terhadap pemberian pinjaman saprodi pestisida dalam program kemitraan PT. ELI sebesar $89,3 \%$ atau 67 responden bersikap baik dan persentase terendah sebesar $10,7 \%$ atau 8 responden bersikap cukup baik, sehingga rata-rata sikap petani 
tembakau terhadap pemberian pinjaman saprodi pestisida berada dalam kategori baik. Pemberian pinjaman saprodi pestisida yang diberikan dalam program kemitraan ini adalah ridomil (fungisida), confidor (insektisida), decis (insektisida), orthen (insektisida), dan prowl (ZPT, penghambat pertumbuhan suli). Pemberian pinjaman saprodi pestisida selama ini cukup bagi responden dalam proses budidaya tanaman tembakau sehingga mereka tidak membutuhkan tambahan pinjaman saprodi pestisida tersebut dalam proses usahataninya. Harga yang ditetapkan juga sesuai dengan kemampuan petani dan lebih murah dibandingkan dengan yang beredar dipasaran serta waktu pemberian pinjaman pestisida juga sudah tepat waktu yaitu pada awal musim tanam.

Persentase tertinggi sikap petani terhadap pemberian bantuan teknologi atau peralatan usahatani dalam program kemitraan PT. ELI sebesar $96 \%$ atau 72 responden bersikap baik dan persentase terendah sebesar $4 \%$ atau 3 responden bersikap cukup baik. Ratarata sikap petani tembakau terhadap program kemitraan berada dalam kategori baik. Teknologi saat ini yang dirasakan tidak hanya berupa teknologi fisik seperti bantuan selang dan pompa air untuk pengairan tetapi juga teknologi informasi seperti laporan prediksi cuaca dan teknik pengendalian hama terpadu.

\section{Sikap Petani Tembakau Terhadap Pemasaran Hasil}

Sikap petani terhadap sistem pemasaran hasil adalah tanggapan atau respon evaluatif petani responden terhadap sistem pemasaran hasil yang meliputi kepastian hasil panen tembakau dari petani yang akan dijual di PT. ELI dan kemudahan penyaluran hasil panen petani ke PT. ELI.

Tabel 5 menunjukkan persentase tertinggi sikap petani terhadap sistem pemasaran hasil dalam program kemitraan PT. ELI sebesar $97,3 \%$ atau 73 responden bersikap baik dan persentase terendah sebesar 2,7\% atau 2 responden bersikap cukup baik. Rata-rata sikap petani tembakau terhadap sistem pemasaran hasil tergolong dalam kategori baik. Responden setuju terhadap sistem pemasaran dalam program kemitraan PT. ELI yaitu hasil panen yang dimiliki oleh responden diterima oleh PT. ELI sehingga responden tidak mengalami kesulitan penyaluran hasil panen yang mereka miliki karena telah menjalin hubungan kerjasama mutualisme antara petani dengan PT . ELI.

Proses mekanisme pemasaran hasil panen dari petani ke PT. ELI dijual langsung ke perusahaan setelah mengalami proses pengeringan dengan kadar air 16,5\% dalam bentuk bale, juga harus bebas dari NRTM (non related tobacco material) seperti plastik, rumput, dan organ-organ atau kotoran binatang. Berat bale yang ditetapkan adalah $50-55 \mathrm{~kg} / \mathrm{bale}$ dengan ukuran standar P x L x T (90 cm x $60 \mathrm{~cm} \times 40 \mathrm{~cm})$.

\section{Sikap Petani Tembakau Terhadap Penetapan Harga}

Sikap petani terhadap sistem penetapan harga adalah tanggapan atau respon evaluatif petani responden terhadap sistem penetapan harga yang berlaku dalam kemitraan PT. ELI. Harga tembakau yang ditetapkan dalam program kemitraan PT. ELI ditentukan oleh kualitas tembakau yang dihasilkan dan dibedakan berdasarkan grade. Terdapat 36 grade yang digunakan disesuaikan dengan posisi daun, warna, dan tingkat kematangan daun.

Sikap petani terhadap sistem penetapan harga dalam program kemitraan PT. ELI tergolong dalam kategori baik sebesar $100 \%$ atau 75 responden. Hal ini menunjukkan bahwa responden setuju terhadap harga yang ditetapkan dalam program kemitraan PT. ELI yang telah mendapatkan kesepakatan harga dasar bersama antara petani dengan perusahaan dan pemerintah sebelum proses pembelian dilakukan.

\section{Sikap Petani Tembakau Terhadap Manfaat Kemitraan}

Sikap petani terhadap manfaat kemitraan yaitu tanggapan atau respon evaluatif petani responden terhadap kegiatan kemitraan yang sudah dijalankan. Tabel 5 menunjukkan sikap petani terhadap manfaat kemitraan dalam program kemitraan PT. ELI tergolong dalam kategori baik sebesar 75 responden atau $100 \%$. Hal ini menunjukkan petani telah dapat merasakan peningkatan keterampilan budidaya tanaman tembakau setelah mengikuti program kemitraan, petani mendapatkan kemudahan dalam penyaluran hasil panen, pemberian pinjaman modal, saprodi pupuk, pestisida dan benih, teknologi atau peralatan usahatani, serta petani dapat meningkatkan pendapatan mereka dan jumlah hasil panen setelah mengikuti program kemitraan PT. ELI.

Sikap Petani Tembakau Terhadap Program Kemitraan PT. ELI Secara Keseluruhan

Sikap petani tembakau terhadap program kemitraan PT. ELI adalah tanggapan atau respon evaluatif petani responden terhadap segala bentuk kegiatan dalam program kemitraan PT. ELI yang terdiri dari beberapa komponen anatara lain tujuan kemitraan, pemberian pinjaman modal, sarana produksi (benih, pupuk, pestisida, dan teknologi/peralatan usaha tani), pemasaran hasil, penetapan harga dan manfaat kemitraan.

Berdasarkan Tabel 5 dapat dilihat bahwa sikap petani tembakau terhadap program kemitraan PT. ELI secara keseluruhan berada dalam kategori baik sebesar 75 responden atau $100 \%$ setuju terhadap segala program yang ditetapkan oleh PT. ELI. Sikap yang demikian menunjukkan bahwa petani menyetujui, menerima dan mau menjalankan dengan baik keseluruhan program kemitraaan PT. ELI dengan harapan dapat membawa dampak yang menguntungkan bagi kesejahteraan petani yaitu adanya peningkatan produksi dan pandapatan.

Hubungan Antara Faktor-Faktor Pembentuk Sikap dengan Sikap Petani Tembakau Terhadap Program Kemitraan PT. ELI 
Faktor-faktor pembentuk sikap yang diteliti adalah pengalaman pribadi, pengaruh orang lain yang dianggap penting, pendidikan formal dan pendidikan non formal. Hubungan antara faktor-faktor pembentuk sikap dengan sikap petani tembakau terhadap program kemitraan PT. ELI dapat diketahui dengan menggunakan uji korelasi Rank Spearman (rs) SPSS 13 for Windows, dengan tingkat kepercayaan 95\% atau $\alpha=$ 0,05. Hasil analisis hubungan antara faktor-faktor pembentuk sikap dengan sikap petani tembakau terhadap program kemitraan PT. ELI di Pulau Lombok dapat dilihat dalam Tabel 6 .

Tabel 6.

Uji Hipotesis Hubungan antara Faktor Pembentuk Sikap dengan Sikap Petani Tembakau terhadap Program Kemitraan PT. ELI

\begin{tabular}{|c|c|c|c|c|}
\hline \multirow{2}{*}{ Variabel } & \multicolumn{4}{|c|}{ Y total } \\
\cline { 2 - 5 } & rs & z-hitung & z-tabel & Keterangan \\
\hline $\mathrm{X} 1$ & 0,602 & 5,179 & 1,96 & Signifikan \\
\hline $\mathrm{X} 2$ & 0,497 & 4,275 & 1,96 & Signifikan \\
\hline $\mathrm{X} 3$ & 0,516 & 4,439 & 1,96 & Signifikan \\
\hline $\mathrm{X} 4$ & 0,635 & 5,462 & 1,96 & Signifikan \\
\hline Xtotal & 0,687 & 5,910 & 1,96 & Signifikan \\
\hline
\end{tabular}

Sumber : Data primer diolah z-tabel $=1,96(\alpha=0,05)$

Keterangan :

$\mathrm{X} 1 \quad=$ Pengalaman pribadi

$\mathrm{X} 2 \quad=$ Pengaruh orang lain yang dianggap penting

$\mathrm{X}_{3} \quad=$ Pendidikan formal

$\mathrm{X}_{4} \quad=$ Pendidikan non formal

Xtotal $=$ Faktor pembentuk sikap

Ytotal = Sikap petani tembakau terhadap program kemitraan

Hubungan Antara Pengalaman Pribadi Dengan Sikap Petani Tembakau Terhadap Terhadap Program Kemitraan PT. ELI

Berdasarkan hasil analisis diperoleh nilai koefisien korelasi (rs) sebesar 0,602 dengan z-hitung sebesar 5,179 dan z-tabel sebesar 1,96, sehingga dapat dilihat bahwa dengan t-hitung lebih besar dibanding dengan $\mathrm{t}$ tabel maka Ho ditolak artinya terdapat hubungan yang signifikan dengan arah positif pada tingkat kepercayaan 95\% antara pengalaman pribadi dengan sikap petani tembakau terhadap program kemitraan PT. ELI, semakin baik pengalaman petani maka semakin baik pula sikap petani terhadap program kemitraan PT. ELI.

Tabel 6 menunjukkan bahwa ada hubungan yang sangat nyata antara pengalaman pribadi dengan sikap petani tembakau terhadap program kemitraan PT. ELI. Hal ini dikarenakan petani dalam memberikan sikap didasarkan pada hasil pengalaman yang telah dijalani terutama yang berkaitan dengan budidaya tanaman tembakau. Semakin banyak pengalaman petani, maka pengalaman yang dimiliki petani juga akan terus bertambah, disamping itu petani menjadi lebih menguasai pengelolaan budidaya tanaman tembakau dan bagaimana mengatasi permasalahan-permasalahan yang ada. Pengalaman yang semakin bertambah menjadikan petani lebih matang dalam mengambil sikap dan keputusan terutama mengenai program kemitraan PT. ELI.

\section{Hubungan Antara Pengaruh Orang Lain yang Dianggap Penting dengan Sikap Petani Tembakau Terhadap Terhadap Program Kemitraan PT. ELI}

Berdasarkan Tabel 6 dapat diketahui bahwa nilai koefisien korelasi (rs) antara pengaruh orang lain yang dianggap penting dengan sikap petani tembakau terhadap program kemitraan PT. ELI adalah 0,497 dengan nilai z-hitung sebesar 4,275 dan z-tabel sebesar 1,96 sehingga dari hasil analisis tersebut dapat disimpulkan bahwa terdapat hubungan yang signifikan dengan arah positif pada tingkat kepercayaan 95\% antara pengaruh orang lain yang dianggap penting dengan sikap petani tembakau terhadap program kemitraan PT. ELI.

Semakin banyak petani mendapatkan saran dari orang-orang yang dianggap penting (Dinas Perkebunan, Kepala Desa, Penyuluh Pertanian Lapang dari PT. ELI, dan Ketua kelompok tani), menjadikan petani merasa bagian penting dalam program kemitraan tersebut, sehingga sikap yang ditunjukkan petani juga semakin baik terhadap program yang dijalankan oleh PT. ELI. Sikap petani yang mendukung program kemitraan diperlihatkan oleh petani dari tingginya minat dan kesungguhan petani dalam pelaksanaan program, sehingga petani merasakan manfaat yang berarti diantaranya peningkatan pengetahuan dan keterampilan dalam budidaya tanaman tembakau dan semakin bertambahnya wawasan atau pengetahuan petani terhadap hal-hal baru selama program kemitraaan tersebut berlangsung.

Petani menganggap Dinas Perkebunan, Kepala Desa, PPL dari PT. ELI dan ketua kelompok tani cukup berpengaruh terhadap sikap petani menerima suatu inovasi. Orang-orang yang dianggap penting oleh petani tersebut menyampaikan segala informasi mengenai program kemitraan seperti informasi seputar pelaksanaan kegiatan budidaya tanaman tembakau, pemasaran hasil ataupun penetapan harga dari tanaman tembakau. Orang-orang yang dianggap penting oleh petani tersebut juga berpengaruh terhadap keputusan yang diambil untuk bergabung dengan program kemitraan PT. ELI.

\section{Hubungan Antara Pendidikan Formal Dengan} Sikap Petani Tembakau Terhadap Terhadap Program Kemitraan PT. ELI

Berdasarkan Tabel 6 diketahui bahwa nilai koefisien korelasi (rs) antara pendidikan formal dengan sikap petani tembakau terhadap program kemitraan PT. ELI yaitu 0,516 dengan nilai z-hitung sebesar 4,439 dan ztabel sebesar 1,96 hal ini menunjukkan hubungan yang signifikan dengan arah positif pada tingkat kepercayaan 95\% antara pendidikan formal dengan sikap petani tembakau terhadap program kemitraan PT . ELI.

Tabel 6 menunjukkan bahwa semakin tinggi tingkat pendidikan formal yang ditempuh oleh petani, maka sikap yang diperlihatkan petani juga semakin baik. Tingkat pendidikan yang semakin tinggi akan 
menambah pengetahuan seseorang dan memberikan wawasan serta pemahaman yang lebih luas terhadap segala bentuk inovasi yang diberikan. Petani dengan tingkat pendidikan formal yang lebih tinggi cenderung memiliki pola pikir yang lebih maju, sehingga petani akan lebih berpikir kritis seperti pada tahap penanaman tembakau, pemberian benih, pemberian dosis pupuk dan pestisida. Petani yang memiliki pendidikan formal yang lebih tinggi cenderung lebih banyak mengajukan gagasan serta pertanyaan kepada PPL dari PT. ELI tentang pelaksanaan program tersebut.

Hubungan Antara Pendidikan Non Formal dengan Sikap Petani Tembakau Terhadap Program Kemitraan PT. ELI

Berdasarkan Tabel 6 diketahui bahwa nilai koefisien korelasi (rs) antara pendidikan non formal dengan sikap petani tembakau terhadap program kemitraan PT. ELI adalah 0,635 dengan nilai z-hitung sebesar 5,462 dan ztabel sebesar 1,96 sehingga dari hasil analisis tersebut dapat disimpulkan bahwa terdapat hubungan yang signifikan dengan arah positif pada tingkat kepercayaan 95\% antara pendidikan non formal dengan sikap petani tembakau terhadap program kemitraan PT. ELI. Semakin tinggi tingkat pendidikan non formal yang pernah diikuti petani maka sikap yang diperlihatkan petani juga semakin baik. Pendidikan non formal yang terdapat dalam program kemitraan ini memberikan manfaat bagi petani dalam menambah pengetahuan mereka dalam budidaya tanaman tembakau sehingga semakin sering mereka mengikuti pendidikan non formal tersebut maka samakin tinggi pula rasa partisipasi, dukungan dan peran aktif petani terhadap program kemitraa PT. ELI.

Berdasarkan hasil analisis secara keseluruhan hubungan antara faktor pembentuk sikap dengan sikap petani diperoleh nilai koefisien korelasi (rs) sebesar o,687 dengan z-hitung sebesar 5,910 dan z-tabel sebesar 1,96 sehingga dapat dilihat bahwa z-hitung lebih besar dibanding dengan z-tabel maka Ho ditolak artinya terdapat hubungan yang signifikan dengan arah positif pada tingkat kepercayaan $95 \%$ antara faktor pembentuk sikap dengan sikap petani tembakau terhadap program kemitraan PT. ELI.

\section{SIMPULAN DAN SARAN}

\section{SIMPULAN}

1. Sikap petani tembakau terhadap tujuan kemitraan, pemberian modal, pemberian saprodi, pemasaran hasil, penetapan harga serta manfaat kemitraan dalam program kemitraan PT. ELI tergolong dalam kategori baik.

2. Sikap petani dibentuk oleh empat faktor, yaitu pengalaman pribadi petani, pengaruh orang lain yang dianggap penting, dan pendidikan formal petani yang termasuk dalam kategori sedang dan pendidikan non formal petani yang tergolong dalam kategori rendah.

3. Hubungan antara faktor pembentuk sikap dengan sikap petani tembakau terhadap program kemitraan PT. ELI adalah :

a. Terdapat hubungan yang signifikan dan positif antara pengalaman pribadi, pendidikan formal dan pendidikan non formal dengan sikap petani tembakau terhadap program kemitraan PT. ELI.

b. Terdapat hubungan yang signifikan dan positif antara pengaruh orang lain yang dianggap penting dengan sikap petani tembakau terhadap program kemitraan PT ELI.

\section{DAFTAR RUJUKAN}

[1] Santoso, K, Tembakau Dalam Analisis Ekonomi. Badan Penerbit Universitas Jember, Jember. 1991.

[2] Hafsah, J., Kemirataan Usaha Konsepsi dan Strategi. PT Pustaka Sinar Harapan. Jakarta. 2003.

[3] Siegel, S., Statistik Nonparametrik: Untuk Ilmu-Ilmu Sosial. Gramedia Pustaka Utama. Jakarta. 1994. 